\title{
Indigenous Tourism in India: Evaluating the Strengths of Mithila Painting Art and Heritage and Suggesting Integrated Marketing Development Approach for Sustainable Promotion
}

Abinash Kumar Jha,* Jitendra Mohan Mishra† and R C Anu Chandran $\ddagger$

\section{Abstract}

Since many generations, the folks of Mithila, more specifically, the womenfolk have been creating a vigorous and distinct style of painting, known for its free hand skating and use of natural colures, carry forwarded from one to another generation through 'mother's-todaughters' tradition. There is a need to investigate the appearance of the art form to develop as tourism resource/product and address the promotional and marketing needs of Mithila Painting. A descriptive approach of the study adopted, the available literature reviewed and categorised in different symmetric groups to explore the likelihood of Mithila Painting as resources for the development of tourism, promotion, and marketing in the region. In addition, in order to suggest marketing strategies for the promotion of art form, this

\footnotetext{
* Pondicherry University, Puducherry, India; avinash2dts@outlook.com † Indira Gandhi National Tribal University, Amarkantak, India; jiteban@gmail.com ‡ Pondicherry University, India; Puducherry; anoos_ind@yahoo.co.in
} 
paper attempted to evaluate internal (the strength \& weakness) and external factors (opportunity \& threats) of Mithila Painting (as a product), and for this purpose secondary data, relevant literature and researcher's observation applied to explore the marketing prospective of the art. The study reveals needs for integrated marketing approach, which recognizes potentials of Mithila Painting along with other resource and contribute to tourism development in the region. Moreover, it is quite obvious to rely on 'locally available resources' regional resources, identification of potential resources as tourism product-mix, promotion and strategic marketing of unique cultural products, specifically, Mithila Painting as one of the burgeoning resources to tourism development in the region.

Keywords: Indigenous resources, Mithila Painting, Tourism promotion \& marketing, Integrated marketing approaches \& strategies

\section{Introduction}

The relationship between indigenous resources and, its promotion and marketing, particularly as a tourism resource is venerable, complex and ambiguous in nature. In the global wake up of 'counter-urbanization and a move towards rural or rural lifestyle/experiences (Dasthgir, Anu Chandran, \& Jha, 2017),followed by the industry's shift from traditional businesses to off-the-beaten-tracks, fuelled by worldwide growing interest and demand for indigenous people and/or their cultural practices, particular for the art forms. Moreover, since the year 1993; when the United Nation designated the year as "International Year for Indigenous People"(Хaxa, 1999). The cultural practices or unique traditional representations of an area/ region, in literature, which is usually mentioned as indigenousorcultural tourism emerged as one of the highly perpetuating and dynamic components of promotional and marketing strategies of the tourism industry. For instance, the marketing and promotional initiatives by the governments of Kerala, Rajasthan, Himachal, Odisha, Ladhak, Tamilnadu, etc. to promote indigenous/ cultural products as 
tourism resource in India. Moreover, literature referred indigenous people as "the native people with unique cultural beliefs and practices closely linked to local ecosystems and the use of natural resources"(Furze, De Lacy, \& Birckhead, 1996) and 'indigenous tourism' as "a form of tourism in which indigenous people are directly involved either through control and/or by having their culture serve as the essence of the attraction"(Hinch \& Butler, 1996).In an ever changing tourists' motivation, say; novelty, authenticity, excitement or adventure (Sibi \& Swamy, 2016), moreover, in a diverse perspectives, Hinch \& Butler emphasized the role of indigenous cultural attractions, indigenous tourism or cultural products and identified as "is characterized by powerful forces for the integration of indigenous people into a global culture on one hand while encouraging indigenous communities to protect and enhance local advantages that may give them a competitive advantage in this global economy on the other" (Hinch \& Butler, 2007).For instance, UN's estimates say; worldwide there are more than 370 million indigenous peoples, belonging to 5,000 different groups spreading across 70 countries and mentions that about $70 \%$ of them live in Asia only. Furthermore, these peoples constitute about $5 \%$ of the world's population but representing about $15 \%$ of the world's poor(UNO Factsheet, 2016).

In this context, India is a strong case at the country is known for its age-old civilization, indigenous people and their unique and diverse cultural practices. India is renowned as "the land that portrayed cultural and traditional vibrancy through its conventional arts and crafts" (Sharma, 2015). Almost every community or regions of India have their own distinct cultural and traditional identities, such as the tradition of folk arts. Study says that the tradition of folk arts or art forms are "very exclusive for that particular regions has its own specialty with regards' to colors, motifs used that symbolized the rich heritage" (Sharma, 2016), which may be viewed across the country in their various predominant forms, unique style, pattern, nature, and practices of art. Moreover, due to its traditional aesthetic feeling and authenticity, these art forms are highly sought after, particularly among the Western art-fans and tourists. It is unfortunate to 
mention that despite immense resources potential and the capacity to attract tourists and the associated benefits for the community/ region, particularly the indigent artist. In general, its seems that both the potential of indigenous resources and their promotional and marketing needs, for instance- unique art forms of a region/ state, were overlooked and the likelihood to develop as a potential resource for tourism development in the region, particularly 'cultural tourism', 'indigenous tourism' and other forms of tourism is considered as a peculiar business in India. This scenario, urge to develop existing and the unique resources- indigenous/ cultural products as a potential resource for tourism development in a particular region, for instance, the indigenous art forms of the Mithila region of Bihar. The folk of the region 'Mathilies' is known for performing a unique tradition of painting, popularly known as 'Mithila Painting' as part of their cultural practices. The art, perhaps one of the best-known genres of Indian folk painting and one among the most famous folk painting under handicrafts (Sharma, 2016) has great demand in domestic as well as international markets. Nevertheless, the strategic marketing and promotion of unique and culturally reach art forms (handicrafts) as a touristic resource, considered as one of the important aspects to develop their own competitive advantage, maintain the unique selling propositions and sustain in the age of stiff competition. Indeed, researchers acknowledged 'indigenous resources' and 'indigenous tourism' as one of the potential options to promote a positive means of development to peoples/communities and an approach to sustain the unique cultural identities of a region. Here for this study on the art of Mithila- 'Mithila Painting' is considered for analysis.

Traditionally, Mithila is acultural expression of one of theancientcivilization of India and mentioned as Mithila Region (Sinha, 2007) in historical records, presently one among the proposed State of India; which would cover the Maithili-speaking regions of North-EasternBihar and Jharkhand(Jagran Post, 2011).Nevertheless, the region is well-knownfor various reasons such as: for its age old cultural-heritage; the birth place of first democratic system- Vaishali; early religious practices; ancient seats 
of learning- Vikramshila; living culture and the house of distinct and rich cultural tradition of art and crafts, for instance 'Mithila Painting', which feature at extremely rich cultural practices, artistic tradition andinnovation. Since time immemorial, the folk of the region, dotsa unique place particularly women practicinga unique art; famous for use of natural colours and their free hand drawing on religious, cultural and traditional themes as part of their cultural practices and tradition.However, in contemporary world, first time, during 1931-33; Mr. William G. Archer (the subdivisional officer of Madhubani during the 1931's gigantic earthquake in Bihar)attempted to the explorationof the art, followed by the active and continuousefforts of Ms. Pupal Jayakar (the then Director of all India Handicrafts Board) during the post drought of 1966-68, Mr. Bhaskar Kulkarni (a Bombay based Artist) and quite a lot from the region, bring the art to the notice of the world (UMSAS, 2017). Thereafter, the ancient and exceptional art of the Mithila region were rediscoveredin order to facilitate sales, as a source of income to ensure survival in the diminishing economy of the region(Mishra, 2003; UMSAS, 2017).Later, the art of Mithila gradually become popular and appreciated all over the world because of its prodigious aesthetic value and at adherence to tradition.Itsseem that based on the popular and major centers of practice and production of the Mithila art, viz. Jitwarpur, Ranti, Rashidpur, etc. which mostly comes under the District of 'Madhubani' occasionally, in recent time, the art is recognized as 'Madhubani Painting' as well.

Madhubani, as a major center of the practice of the Mithila Painting, is easily accessible from every corner of the world. The districts headquarter and city- Madhubani is adirect connection with the major cities of India through rail and road network and well connected through major airports in the region. The capital city of Bihar; Patna is the nearest airport, which could be approached by approx. five hours of the drive $(135 \mathrm{Km})$ from the Madhubani (See, Map-1 for the location of Madhubani). Besides, the city is easily accessible from the airports of Ranchi, Kolkata, and Varanasi. 


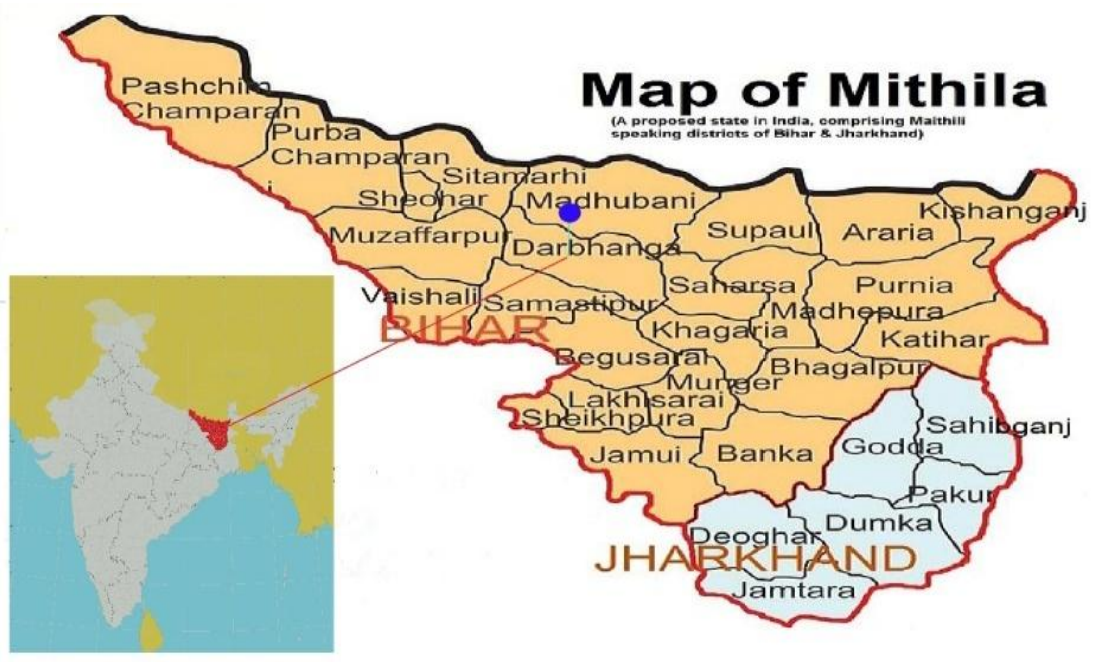

Map 1 Location Map of Madhubani, Bihar

Moreover, in India, handicrafts being an unorganized sector of theeconomy, as there is alack of production, sales,exports and artisan data for a particular art form, specifically, data on the tourist to the region,expenditure on the art form andtheir significance to the socio-economic upliftment of the community/ region. Although, according to the officials of the Marketing and Service Extention Center (Handicrafts), Madhubani; in 2015, there are more than 26,000 artists registered as 'Artist of Mithila Painting' under the jurisdiction of the office, besides equivalent innumber registered with other States and/or regional offices. Moreover, the export statisticsfor handicrafts reveals that under the specific category of handicrafts "Painting, Drowing and Pastels" the Mithila (Madhubani) Painting occupied a dominant and promising position in India. In the financial year 2016-17; the export of Mithila/ Madhubani Painting mounted at all time high, with 925.35\% rate of growth (against US\$ 1.69 of 15-16) shown impressive growth in export and account forUS\$ 17.37 million $(9.34 \%)$ against total export of US\$ 186 millionin thecategory of "Painting, Drowing and Pastels" (Department of Commerce, 2017).The painting is popular among the western art lovers and triggers demand from UK, USA, HongKong, Nepal, Canada, 
Vietnam SOC Republic, Germany, Australia, UAE, Singapur, Switzerland, Denmark, Mauritius.etc. Moreover, to handle, the emerging demands of the art of Mithila, as per estimates in total 89 showrooms are functioning within the state, besides, artists, NGOs, and vendors are spread across the major cities of the country, including foreign countries such as USA, UK, Japan, Germany, Nepal. In context of tourist visits to the region (based on dataon the centers of Vaishali, Muzaffarpur, Sonpur Fair, Bhagalpur, Raxual, Madhepura and Madhubani) estimates reveals that in 2014; against 21588306 domestic and 765835 foreign tourist to the state total $89,73,625$ domestic and 95,937 foreign touristsvisited the regionand accounts for $39.80 \%$ and $11.56 \%$ of tourist to the state respectively(Department of Tourism, 2016).

\section{Need for the study}

Itis observed thatregardless of the competitive strength, its perceptional value and emerging demands for Indian art and crafts, particularly indigenous cultural artistic products in international and domestic markets, the government as well artistic organizations failed to explore the potential and existing opportunities. Correspondingly, the unique and traditional folk art of Mithila 'Mithila Painting', due to mysterious reasons received comparatively little attention for the promotion and marketing as a tourism resource and lay minimal attention to attract tourist through the art and crafts of the region.However, besides the art form, Vaishali, Madhubani, Motihari, Sitamadhi,Darbhanga, Begushari, Sahrsa, Madhepura, Bhagalpur and sites in the Districts of West Champaran- Valmiki Nagar, Nandangarh, Rampurva are the most significant and prominentdestinations to visit in the region. Nevertheless to say, most of the existing attractions and potential resources in the region such as cultural-heritage, historical sites, religious places, natural attractions, art forms and crafts (handicrafts/handlooms) are intact and gradually deteriorating their values due to indifferent political outlook, lack of efforts for preservation and production of the sites, awareness among local communities, visitors and officials, and absence of means to develop on the strength of resources in the region. 
In the scenario, this study set to explore the one aspect of regional resource- 'Mithila Painting' and their prospects of promotion and marketing as a potential tourism resource and one of the element to initiate tourism development in the region. Therefore, in order to address the main objectives, a descriptive approach of study adopted and availableliterature is reviewed to explore the prospect of Mithila Painting for their promotion and marketing needs. Therefore, for this study,relevant and availableliterature is reviewed and categorized in broad groups, namely-indigenous tourism, indigenous and cultural resources, cultural tourism marketing, cultural-heritage of Mithila, Mithila Painting, integrated marketing approachand strategies for the arts. The present study attempted to evaluate the role of marketing for indigenous and cultural tourism with a special reference to Mithila Painting. In addition, based on the analysis of secondary data, review of literature and researchers' observations, this paper attempted to evaluate the strengths, opportunities, threats, and weaknesses of Mithila Painting in order to suggest marketing approaches and strategies, to develop as potential resources for tourism development in the region. Thus, this study is an attempt to explore the scope for marketing in the promotion of Mithila Painting as a potential tourism resource and strengthening the indigenous and cultural resource base of the region. Besides, through this at work, the researchers are optimistic to provide an alternative move to the marketing and promotion of indigenous resources and challenges the popular over optimized traditional approach of socio-economic prosperity.

\section{Review of Literature}

In relation to tourism, literature identified needs of promotion and marketing of indigenous resources, its cultural products, as well as tourism (Hall, 2007; Ryan, 1997; Sibi \& Swamy, 2015; Weaver, 2010) and the issue and challenges of tourism develop upon unexplored resources (Getz \& Jamieson, 1997; Sibi \& Swamy, 2015; Sinclair, 2003). In addition, the nature, structure and specific features of indigenous or cultural tourism business are studied. Smith (1996), in his study on 'tribal tourism' at Acoma Pueblo, New Mexico 
(USA) observed that the trade "involves small-scale enterprises that are labor intensive for an owner, a family, or a small tribe" and mentioned, indigenous peoples typically involves small businesses based on the inherited tribal knowledge of culture and nature (Smith, 1996). Studies highlighted the significance of stakeholder's participation in development as well as promotion and marketing of indigenous/ cultural tourism (Hall, 2007).

However, Sinclair (2003) affirms, 'marketing': as a key challenge in growing interest and increasing number of travelers, seeking more experiences- that are authentic will have been favored. Further, he added, the next imperative will be to refine the product and commence effective marketing and argued, appropriate \& effective marketing is a vital ingredient in the enterprise of indigenous tourism if it is to be economically viable and produced rewards for the local community (Sinclair, 2003). Getz \& Jamieson (1997) identified infrastructure as an area of concern for marketing and said, "Indigenous tourism attractions are often located in rural or remote regions with limited infrastructure facilities" (Getz \& Jamieson, 1997). Moreover, factors such as inadequacy of marketing policy (Sinclair, 2003), lack of attention to indigenous art forms \& cultural attractions, that does not stress on the touristic value of indigenous arts and culture in order to enrich experiences. Furthermore, earlier researchers observed the need for 'careful and sustainable approach' to take indigenous or cultural tourism to a higher level (Ryan, 1997; Sibi \& Swamy, 2015; Smith, 1996; Weaver, 2010). In this context, the need for sustainable tourism practices for protecting the rich biodiversity and preserving the indigenous culture (of Wayanad) would be a focus on the conservation of biodiversity (Sibi \& Swamy, 2015). Moreover, they suggested, it is possible only when "conservation activities and tourism development reciprocate each other" (Sibi \& Swamy, 2015). In addition, studies established that "indigenous tourism promotion contributes to the sustainable development of a region" (Sibi \& Swamy, 2015). In the scenario, the global policies and strategies guiding to such practices that ensure utilization of resources such as cultural resources (in the perspective of development and 
tourism) be in the line with principle of sustainable development (Ryan, 1997; Ryan \& Page, 2000; Smith, 1996).

In the phenomenon, tourist involved with different motivation and they have different expectations about their experiences, many of them wish to have different and novel experiences such as indigenous/ culture expressions of a region. However, the prime reason to visit indigenous tourism destination is the opportunity to experience the variety in indigenous culture, "the uniqueness in experiencing indigenous life, culture, tradition, and ethnicity attracts tourists to aboriginal attractions" (Sibi \& Swamy, 2015). Moreover, in the context of indigenous tourism, studies emphasized the problems of 'haphazard and rushed pursuits of tourism develop', and recommended for planning, development and specific policy (Sibi \& Swamy, 2015; Sinclair, 2003; Zeppel, 2001). In this context, Sibi says that sometimes this approach of development (unplanned one) may lead to unwanted problems, which would hurt the sentiments and emotions of the native people (Sibi \& Swamy, 2015).More specifically, Piore mentioned issues and concern on 'rush and unplanned development of indigenous tourism' and their consequences on 'the life of native' (Piore, 2002), the concern attempted to address by Sibi \& Swamy's study on Wayanad. In their study, they highlighted the significance of 'a well-organized', 'planned' and 'sustained effort' that ensure involvement of indigenous people in the process of tourism development and mention that, "is essential for the success of indigenous tourism destination" (Sibi \& Swamy, 2015). They further believed that "Unless there is a clear policy, which respects safeguarding indigenous sovereignty, promoting indigenous tourism in its original meaning, may not be practical" (Sibi \& Swamy, 2015). Likewise, Sinclair recognized needs for policy and says, "Unless there are clear policy prescriptions that recognized, respect and safeguard indigenous sovereignty over the resources that is the basis of indigenous tourism, an important infrastructure will be missing" (Sinclair, 2003). 


\section{Indigenous Tourism}

In 1977, Indigenous tourism emerged as a legitimate field of academic enquiry, when Valene Smith's work 'Hosts and Guests: The Anthropology of Tourism' came out of print; the work considered as one among the earlier work which started a period of anthropological investigation of the subject (Butler \& Hinch, 2007). Followed by a "critical advocacy" phase of the engagement, and then by a policy and strategic economic development phase, which further refined and analyzed the contentious tri-lateral relationship between indigenous communities, protected areas, and ecotourism. However, the enthusiastic participation of social scientists such as geographers, economists, and sociologists increase multidisciplinary and interdisciplinary approach in the field. Subsequently, due to its anthropological roots, sometimes early researchers regarded indigenous tourism as a subset of "cultural tourism" (Blundell, 1995) or "ethnic tourism"(Pitchford, 2006). However, researchers attempted to describe and define the field of study in their different views and perspectives (Sibi \& Swamy, 2015; Sinclair, 2003; Swain, 1989). For instance, Sinclair, in order to give clarity to the subfield, considered this as, an inter-disciplinary phenomenon within tourism studies by taking into consideration it as a subset of "alternative tourism" and eco-tourism(Sinclair, 2003). Furthermore, Swain in his study on 'China' referred indigenous tourism as, "tourism based on the group's land and cultural identity and controlled from within by the group" (Swain, 1989).

Hinch and Butler (in 1996) visibly identified the term 'indigenous tourism', initiated effort and seriously attempted to define indigenous tourism as a broader and more autonomous body of knowledge (Hinch \& Butler, 1996; Hinch \& Butler, 2007). Moreover, in their remarkable contribution to the field of study, they defined indigenous tourism as: "tourism activity in which indigenous people are directly involved either through control and/or by having their culture serve as the essence of the attraction" (Hinch \& Butler, 1996). 


\section{Indigenous Resources, Cultural Products, and Tourism}

Tourism is undoubtedly a significant economic, socio-cultural and political phenomenon and has identified as a basis for indigenous peoples and communities to develop a better socio-economic future (Deutschlander \& Miller, 2003; Fuller, Buultjens, \& Cummings, 2005; Hinch \& Butler, 2007; Sibi \& Swamy, 2015). During the Fulbright Symposium on, 'Indigenous cultures in an interconnected world', held in Australia in 1997,Sylvia Kleinert (2010) stated that 'indigenous tourism is now important to cultural survival' and added "for many aboriginal communities, tourism development offers a way to overcome social isolation" (Kleinert, 2010). Moreover, Dockery talk about diversity of resources within the community/ culture and alleged, sometimes we address 'Indigenous culture' as one homogenous culture and argued, "there is, in reality, considerable diversity among Indigenous peoples from different tribes and regions, as well as many different Indigenous languages" (Dockery, 2010). In this context, UNESCO says that; "Cultural heritage is the legacy of physical artifacts and intangible attribute of a group or a society that are inherited from past generations, maintained in the present and bestowed for the benefits of future generation" (UNESCO, 2017). Notably, this definition address both tangible as well as intangible representation of a culture- "including everyday objects such as clothing and dwellings, as well as arts in its many representations- from pottery and beadwork to painting and sculptures and the other, less physical but equally important, aspects of traditional lifeways such as language, oral stories, customs and beliefs (Roy, 2015).

Smith \& Butler proposed 'Four-H' structure for indigenous tourism as; Habitat, Heritage, History, and Handicrafts (V. Smith \& Butler, 1996) and they described indigenous tourism phenomena as a cultural-bounded visitor experience added, in literature, it as micro-study of man-land relationship. Besides, in order to the evolution of the relationship between tourism and indigenous peoples, David Weaver, in 2009 proposed 'a six-stage model of evolution' and suggested the empowerment and sustainability implication of the model (Weaver, 2010). Nevertheless, to say, it 
seems that academician and researchers attempted to deliberate and described the term 'indigenous tourism', 'indigenous culture' and 'cultural tourism' in their diverse context and perspective. In this paper, in view of its root, approaches and the natural connection with each other, for further discussion the phenomenon of indigenous tourism or indigenous culture considered as one of the taxonomy within the broader area of cultural tourism or cultural studies.

\section{Mithila: The land of Cultural Heritage and Indigenous Resources}

Mithila is one of the main traditional cultural and political division of the state of Bihar, since ancient time, which has its own sociopolitical and cultural history that gives the region unique position in the history, contributed to a 'distinct identity' from other, such as 'Magadha'(Kumar, 2005; Sharma, 1979; Sinha, 2007; Thakur, 1988). The land 'Mithila' has been widely known as a great set of culture and its association with 'Janaka'; "the celebrated saint-king of ancient India tradition" (Mishra, 1978), 'Sita'; the idol and wife of Lord Rama in the epic 'Ramayana' (Sharma, 1979). The land is also known for birthplace of several exceptional individuals in the Indian history, the rise and fall of great monarchies and republics (Thakur, 1988), heritage, archeological \& ecological sites (Mishra, 1978), socio-political echo and cultural tradition \& practices such as 'Mithila Painting'(Archer, 1949; Jain, 1989; Mathur, 1966; Mishra, 1978; Rekha, 2003; Sharma, 1979; Sinha 2007),overall have linked the region with the rise of culture in eastern India from extremely ancient days (Mishra, 1978).

In the Early Vedic period, (In South Asia began about 1500 BCE) several kingdoms existed in the plains of Bihar and one among them was known as 'Vidheha' and Mithila was the capital of that kingdom (Sharma, 1979). In this context, Britannica mentions as, "north of the Ganges was Videha, one of the kings of which was the father of Princess 'Sita', the wife of Lord Rama and the heroine of the Ramayana, one of the two great Hindu epic poems of India".Historically, the region documented as Thrubhukti, Tirhute or Tirahut(O'Malley, 1907; Roy Chaudhury, 1964; Sharma, 1979; Thakur, 1988) is a geographical expression of the 'Mathili culture' 
and tradition (Kumar, 2005; Sharma, 1979; Thakur, 1988) and “laying between $25^{\circ} 28^{\prime}$ and $26^{\circ} 52^{\prime} \mathrm{N}$ latitude and between $84^{0} 56^{\prime}$ and $86^{\circ} 46^{\prime}$ E longitudes"( $\mathrm{O}^{\prime}$ Malley, 1907). Moreover, in ancient records, the region is found to "bounded on the north by the Himalaya, and on the east, south and west by the rivers Kosi (Kausiki) Ganga and Gandaki respectively" is a well-marked natural region with its size varying in different ages, says (Thakur, 1988).

Historically, the region is comprising districts of North Bihar 'terai', the southern portion of the kingdom of Nepal (Mishra, 1978). At present, one among the proposed State of India; which would cover the Maithili-speaking regions of North-Eastern Bihar and Jharkhand (Jagran Post, 2011).In addition, besides the distinctlinguistic and cultural identity, the poor economic development and political indifference for the region are among the several other factors which lead to demand for separatestatehoods(Jagran Post, 2011). There is the difference in opinion among historian, writers, and academicians about the term 'Mithila', its origin and relevance. In the context, historian Uppender Thakur says that "The origin of the word 'Mithila' and 'Videha' is purely mythical" (Thakur, 1988) and the region called "Mithila Region" named after the capital city of an ancient kingdom called "Videha"; represents the people of this land and possessing a distinct cultural identity (Thakur, 1988). Moreover, in pre-historicliterature, the region is emphasized as 'one among oldest' and occupied a unique position (Sharma, 1979), "which played a significant role in the evolution of ancient Indian composite culture" (Kumar, 2005). In this context, dated back in 1956, Upendra Thakur, in his remarkable contribution to the land 'History of Mithila' provides a systematic and detailed account on 'Mithila'; the land, its people, philosophy, history, socio-economy prominence, culture and practices from the earliest time to 1556 AD. In contemporary literature, the contribution of 'Upendra Thakur' to the land and the people, perhaps, one of the primary and authentic source of information on the land 'Mithila', its history and culture. Furthermore, ancient literature referred 'the land' as one of the oldest inhabited placesin the world, and the 14 
original peoples of the land are known as 'Maithilies'- valued rich cultural heritage and home to many native art forms and cultural practices (Sharma, 1979).

\section{The People 'Maithilies'}

The 'Maithilies' are probably the descendants of some of the original inhabitants of India living in various parts of the country particularly in the districts of Bihar, Nepal, Jharkhand etc. The natives of this land 'Maithilies' are considered as indigenous to the land and have managed to preserve many of their tradition, culture, and customs despite many oppressions and atrocities from other communities. Besides, their unique cultural heritage and practices, the natives of this land are also significantly known for its medieval and modern regional language, called "Mithili" (Mishra, 1978), famous for its 'sweetness' and the rich literature practices. Moreover, Prof. Narandra Kumar Sinha 'Nirala' mentioned, despite marginalization of society, continuous socio- economic isolation and several horrible oppression on residents of this land, have greatly retained their age-old cultural tradition and maintained a higher level of ethics in their social practices (Sinha, 2007). Furthermore, they know for their faith, established practices, and soft-spoken nature, superior \& hospitable characteristics and normally do not cheat, tell lies, and do other misdeeds, which others often do. In view of gradual decline and misrepresentation of ancient Mithila culture and heritage, Prof. Sinha argued that "It is time now to promote the land's unique culturalheritage and artistic strengthen to mainstream them"(Sinha, 2007).

\section{Cultural and Heritage Resources of Mithila}

Mithila is the land where the traditional Hindu cultures until lives to regulate the life of the people(Kumar, 2005). Besides, it's exceptional and ancient cultural heritage, the land is also famous as the birthplace of several great people, the rise and fall of great monarchies and republics (Thakur, 1988), heritage, archeological \& ecological sites (Mishra, 1978), socio-political echo and cultural tradition \& practices. The arts of Mithila 'Mithila Painting' (Archer, 1949; Jain, 1989; Mathur, 1966; Mishra, 1978; Rekha, 2003; Sharma, 
1979; Sinha, 2007) is one among the world famous art forms have linked the region with the rise of culture in eastern India from extremely ancient days (Mishra, 1978). In addition, several others art and crafts such as Sikki Crafts, Bhagalpuri Silk, Mapier Mache, Bambo and Cane Crafts, Sujani, etc. are produced in the region. In the post-independence period, the excavation works done by Archeological Survey of India (ASI) on the sites of Kesariya, Raja Vishal ka Garh in Vaishali, Rampurva, Lauriya Areraja, Lauriya Nandangarh, Naulagarh in Begusarai, Balirajagarh in Madhubani district, etc. has restored the link to cultural heritage and historical importance of the region.

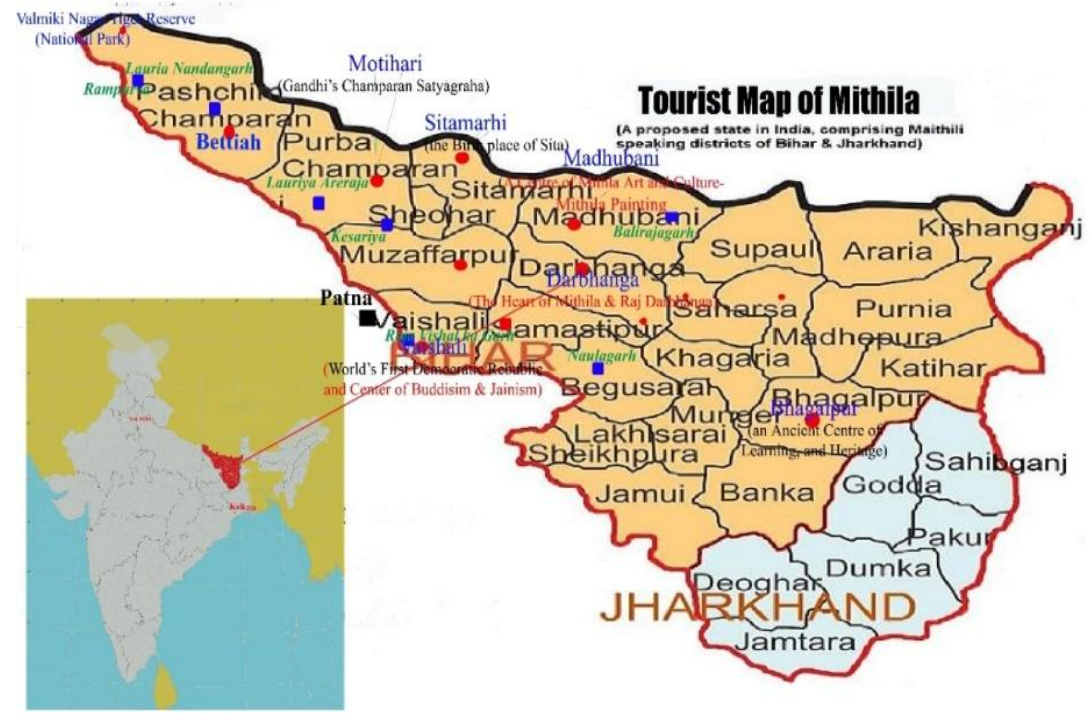

Map 2 Tourist Map of Select Districts of Mithila

Source: Author's elaboration, based on data gathered from various sources.

However, based on their responsiveness and the motivation to visit, the various existing and potential resources of the region, could be broadly classified into following categories:

- Places of Religious Importance-Buddhism, Santana Dharma, Jainism \& Islam 
- Archeological/Historical Sites-Balirajagarh, Darbhanga, Lauriya Areraja, Lauriya Nandangarh, Vaishali, Naulagarh, etc.

- Natural/ Ecological attractions-Wildlife Sanctuaries, National Parks, Bird watching, etc.

- Cultural Motives-Arts and Craft, Mithila Painting, Bhagalpuri silk, etc.

- Fairs \& Festivals-Surastha Sabha

The most significant destinations to visit are; Motihari, Vaishali, Madhubani, Darbhanga, Sitamadhi, Begushari, Sahrsa, Madhepura, Sites in the districts of Champaran- Valmiki Nagar, Bhagalpur etc. Most of the existing and potential resources in the region such as cultural-heritage, historical sites, religious places, natural attractions, art forms and crafts, and several others.

\section{The Art of Mithila: Mithila Paintings}

The popular art of Mithila, 'Mithila Painting' is consideredas traditional folk and an indigenous art of the region. According to the description of ancient literature such as Ramayana, Mahabharata, and Purana, 'the art' originated and practicing since the time of Rama-Sita Marriage in Mithila (Jain, 1989; M\&SEC, 1999; Mishra, 1978; Sharma, 1979). It believed that King Janakahad asked for paintings to develop for his daughter Sita's wedding. Tulsidas had given an elaborate description on how the entire Mithila region of Bihar decorated for the marriage, "those decorations consisted chiefly of vivid murals depicting mythological personages, deities of the Hindu pantheon and flora and fauna of the region" (Cited In:Sharma, 1979).

Although, since time immemorial, the folk of the region, specifically the 'women's folk' practicing a unique art form within their premises as part of their cultural practices and tradition. But, in the contemporary world, only after the 1931's gigantic earthquake of Bihar, the art was exposed to the world, when then asubdivisional officer of Madhubani; Mr. William G. Archer got an opportunity to discover the ancient and exceptional painting on the 
newly exposed interior walls of Mithila homes (UMSAS, 2017). Later in the post drought of 1966-68, the then Director of all India Handicrafts Board, Ms. Pupal Jayakar sent Mr.Bhaskar Kulkarni (a Bombay based Artist) to Mithila to encourage women to duplicate their mural paintings on paper and clothes, in order to facilitate sales, as a source of income to ensure survival in the diminishing economy of the region(Mishra, 2003; UMSAS, 2017).Thereafter, along with continuous efforts of government agencies, NGOs, artist community and with the supports of various initiatives, the painting gradually become popular and both the art and artists are appreciated all over the world because of its prodigious aesthetic value and at adherence to tradition.Moreover, the art is recognized, appreciated and honored at regional, national and international platforms. So far, the five finest artists of the art form conferred with 'Padam Shree Award' [Jagdamba Devi (1970), Sita Devi (1975), Ganga Devi (1976) , Mahasundari Devi (2010), Baua Devi (2016)], 3 'Shilp Guru Award' (Sita Devi, MahaSundari Devi (1997), Godawari Dutta), 2 TulshiSaman (Ganga Devi, MahaSundari Devi), more than 12 'National Award' (viz. Jagdamba Devi, Sita Devi, Ganga Devi, Godawari Dutta, Mahasundari Devi, Shanti Devi, SiwanPaswan, Baua Devi, Yamuna Devi) along with several 'State and Regional awardees.

However, Mithila Painting has a unique tradition and practices, which is associated with nature, beliefs \& practices of natives and represents a geo-cultural transformation in the region (Archer, 1949; Heinz, 2007; Nigam \& Ranjan, 2014; Sharma, 1979). Undoubtedly, the art of Mithila is the only art form, which dominated by women and surviving since many generations (Mathur, 1966; Sinha, 1999a; Sinha, 2003). Furthermore, which is thriving "from generation to generation, the womenfolk of Mithila in the state of Bihar have produced a vigorous and distinctive painting as part of their religious and cultural heritage" (Sinha, 1999c). The skill handed down from one to another generation, and hence the traditional designs and patterns are widely maintained. Traditionally, there are three styles of painting; first, Kachni- in which only line work, usually monochrome, second, Bharni- in this style of painting the subjects are filled with solid color and third, 
Godhana- the figures appear in concentric circles on parallel lines (M\&SEC Madhubani, 1997; Ministry of Textiles, 2017; Sinha, 2007). Conventionally, the paintings are religious in nature and traditionally done for a ceremonial or ritualistic purpose, mostly practicing on freshly plastered or a mud wall in the special rooms in their homes (in the puja room, ritual area, bridal room), on the main village walls, etc. (Rekha, 2010; Sinha, 2004). Figures from nature \& mythology are adapted to suit their style. The themes \& designs widely painted are the worship of Hindu deities such as Krishna, Rama, Siva, Durga, Lakshmi, Saraswati, Sun and Moon, Tulasi plant, court scenes, wedding scenes, social happenings around them, etc. Floral, animal and bird motifs, geometrical designs used to fill up all the gaps. There is hardly any empty space in this style (Ghosh, 2013; Jain, 1989; Sharma, 2016; Singh, 2004).

However, in order to explore issues and challenges of the artisans in the region, during 1999, the Marketing and Service Extension Centre, Madhubani (a unit of Ministry of Textiles, GoI) conducted a special study on Mithila Painting. The study revealed that poor economic conditions of artists, absence of support system and several internal and external factors lead to use of low-quality rowmaterials (as an alternative to traditional natural colures and materials), use of traditional techniques and tools in the production process, lack of design innovation, ineffective sales channels and lack of promotional and marketing efforts. Subsequently, replicated in inferior quality of art, high cost of production and lower brand value in the market, followed by relatively low selling, lowering income opportunities, lowering standards of living, and so, majority of artisans are found to be poor and forced to live under poverty threats in the region (M\&SEC, 1999). In addition, thestudy emphasized that artisansin the region are facing several issues such as lack of supply-chain mechanism, craft bazaar, exhibition centers and the problem of an insufficient marketing system of the art forms. Moreover, the alleged role of intermediaries and a shortage of provision for a cred its facility for the artists is another major challenge to promotion and marketing of the art. Regardless of several productions, promotional and marketing issue and challenges of the Mithila Painting, it has found that "still there is no 
shortage of demand because of exclusiveness of their product" (M\&SEC, 1999).

According to the office of the Development Commissioner (Handicrafts), Marketing \& Service Extension Centre, Madhubani, in 2015; within the jurisdiction of the office more than 26,000 artists registered for the Mithila Painting and engaged in the process of production, sales and promotion of the art forms (directly or indirectly) in the region. Moreover, it was believed that every single piece of the artis unique and distinct from other; this production exclusiveness (natural expression of artists) seems to be an advantage for art and craft but become a disadvantage in case of mass production. In 2007, with the efforts of the government of Bihar and the office of M\&SEC, Madhubani, the Mithila Painting is registered as Geographical Indication (GI). In 2017, one among the 149 handicrafts and handloom selected for the GI registration in India and one out-off four from the state of Bihar (Ministry of Textiles, 2017).However, in the very context, its seems that despite the increasing focus given to indigenous resources and its cultural products such as art forms- handicrafts/handlooms in the policy and development initiatives in India.Studies conveyed that, in general, "tourist's perspectives of indigenous tourism" (McIntosh, 2004), development of indigenous cultural products and its application for marketing and promotion remains underresearched (McIntosh \& Ryan, 2013).

\section{Handicraft's Promotion \& Marketing in India: An Overview}

In the global emerging phenomenon of tourism and, ever flourishing global demand for arts and artistic products. The potential of tourism, specifically, inherent Indian cultural resources- such as the art forms, handloom and handicrafts, their relationships with the development of tourism and prerequisites of promotion and marketing recognized as one of the approaches to transform at of at the communities as well as the industry as a major engine of growth and prosperity (Ministry of Tourism, 2002). In the context, in India, the textiles policy document identified the potential of the handicrafts sector "to enable the sector to increase both its contribution to exports and its productive employment. 
Initiatives will include up-gradation of skills, creation of better work environment, design and technology intervention, development of clusters for specific crafts with common service facilities, improvement in infrastructure, and market development" (Textile Policy, 2000).Therefore, in a dynamic and competitive market, promotion and marketing of cultural products viz. handicrafts, handlooms and other artistic products considered as one of the crucial tasks in the specific context of tourism marketing. However, the first time in 1992, the National Action Plan for Tourism (India) identified the need for 'effective marketing strategies' as one of the major approaches for achieving tangible results for the inclusive well-being and quality of life of the inhabitants (Singh \& Singh, 2000).

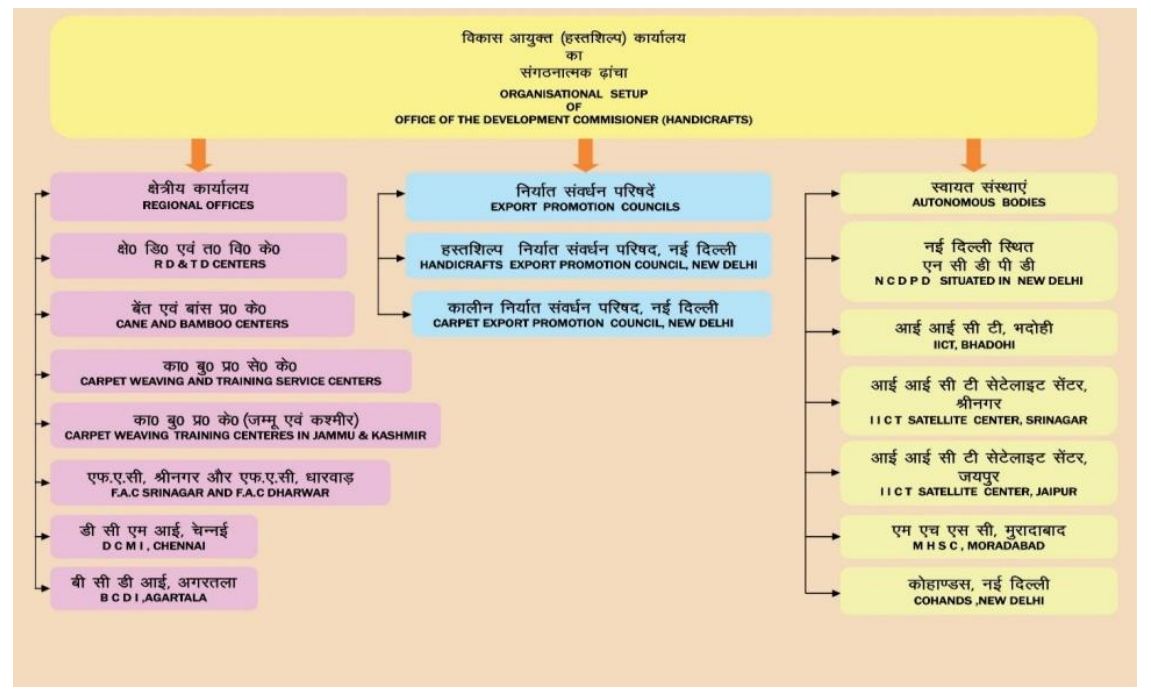

The organizational Setup for the handicrafts in India (DC-Handicrafts)

Source: organizational structure, (DC (Handicrafts), 2017)

At the national level, the Ministry of Culture is the nodal agency for preservation and promotion of art and culture. In order to preserve diverse cultural resources and its various forms of arts, particularly, handicrafts and handlooms, the Ministry of Culture along with the Ministry of Textiles and its various agencies (national/ state) working together to production, distribution, 
research, development of art forms in order to protection of interest of stakeholders/ artisans. In addition, there are a set of specialized agencies such as1) Office of the Development Commissioner (Handlooms), 2) Office of the Development Commissioner (Handicrafts), 3) Handicrafts and Handlooms Export Corporation of India Ltd., 4) National Handloom Development Corporation Ltd. (Lucknow), 5) All India Handloom and Handicraft Boards, 6) Handloom Export Promotion Council (Chennai) and 7) Export Promotion Council for Handicrafts (New Delhi) working together for the development and extension of export promotion of handloom and handicrafts in India. In addition, the marketing of art and crafts done through two different channels, first, ECommerce platforms such as the handicrafts and handloom exports corporation of India Ltd., India handmade bazaar, and second, by state corporations such as the Bihar State Small Ind. Corporation Ltd. In the financial year 2013-14, the department of industries, Government of Bihar sanctioned only two crores for the production and marketing of handloom and handicrafts in the State.

Moreover, the Development Commissioner (Handicrafts), as a specialized agency for handicrafts in India recognized the role and significance of handicrafts as "Indian Handicrafts Sector has emerged as one of the most important foreign exchange earners for India on a sustained basis thereby playing a vital role in the economic development of the country" (DC (Handicrafts), 2016). Consequently, continues focused attention given to handicrafts and handloom sector in India. In the context of promotion and marketing of handicrafts, under the schemes of 'market support and services' thrust given to address the promotional and marketing needs of handicrafts, and provisions made for various activities. For instance, buyer and seller meet (India and Abroad), folk craft festivals, cultural exchange programmes, publicity via internet, provisions for international crafts expository, market studies, exhibitions at established malls and cities and, regular demonstration, promotion and sales of crafts through various means such as: integrated handicrafts events, national handicrafts fair, crafts fairs, exhibitions, Gandhi ShilpBazaar. In all-purpose, 
the office of the Development Commissioner (Handicrafts) aimed at providing support to individuals, groups and cultural organizations engaged in production and promotion of handicrafts in India, implements a number of programs under various schemes. The office running schemes/ programs, namely 1) Baba Saheb Ambedkar Hastshilp Vikas Yojana, 2) Exhibition, 3) Design \& Technical Development, 4) Skill Up-gradation Training, 5) Workshops, 6) Workshed, 7) Common Facility Service Centre, 8) State Initiative Design Centre, etc. Besides, said office also implementing various schemes under 'welfare measures' for handicrafts artisans such as1) Artisans datasheets and Issue of Identity card to the artisans, 2) Group Insurance Scheme through LIC's Janashree Bima Yojana for artisans, 3) Artisans Credit Card/ Credit Guarantee Scheme, 4) Financial Assistance (Pension) under indigent circumstances and 5) National Award Scheme.

In the specific context of the art of Mithila- 'Mithila Painting' its seems that despite the aesthetic and perceived value for the art, and growing popularity in domestic and international markets, the art forms of the region received less attention for the promotion and marketing needs by the national, state and regional agencies. There is no doubt that the art has grown within the set framework, but relatively less done to address its needs for promotion and marketing in a broader perspective. That is why; the art and artisans of the region fail to receive much intervention through the initiatives from the above structures for the production, promotion, and marketing of handicrafts in India. Except for few initiatives and efforts, the promotion and marketing of Mithila Painting aremostly had driven by individual artists, NGOs and private entrepreneurs with their stake in the art.

\section{SWOT Analysis}

The role of indigenous resources, their cultural products such as art forms, crafts and its contribution to tourism, development, and marketing is relatively overlooked in India's national development priorities and strategies (marketing). A review of Mithila Painting as a fabulous cultural product identifying its competitive strengths and weaknesses, opportunities, and threats shows that the 
indigenous art forms of Mithila region of Bihar has considerable potential for promotion and marketing and to develop as one of the major touristic resources of the region. The main outcomes of the analysis are:

From a tourism point of view, at Mithila Paintings' possess great competitive advantage which is its association with one of the ancient civilization 'Mithila' (one of the earliest center of religious endeavours, known for its cultural heritage, world's earliest seat of higher learning and practices and its diverse forms of arts), its cultural tradition and practices, tradition of free-hand sketching, aesthetic and cultural values. The aesthetic and perceived values distinguish the art form from others, down the line created a brand value in the market, which helps to attracts visitors across the globe- travelers, researchers, art lovers and special-interest tourists. In this context, Prof. N. N. Sinha said, irrespective of their age and class, the region has much to offers to tourists and has long records of receiving both domestic and international travelers, tourists and art lovers to experience and admire the art forms of Mithila, particularly 'the Mithila Painting' - known for its unique traditional style, artistic value and practices.

The main competitive constraints as regards competition faced by the tourism sector in general and the Mithila Painting, in particular, are low priority and policy initiatives by the government and allied agencies. It seems that both Central and State governments are unable to effectively link the unique cultural products of the region such as Mithila Painting, its potential and role, and prospects for promotion and marketing. Besides, sector specific bottlenecks such as low level of tourist infrastructure, facilities and services, community specific issues such as lack of awareness, fondness with own cultural heritage and initiatives of conservation, development and promotion of locally available resources as tourist attractions are the major constraints for marketing of arts forms and tourism development in the region. In addition, the conventional perception about safety and security concerns of visitors to the state, role of stakeholders, lack of promotion and effective supply channel for the art form, limited availability of information in source markets and at the destination, and insufficient efforts to 
marketing of regional resources are other issues for the promotion of art form.

Notwithstanding the constraints, the art form has established its strength for development and marketing, and opportunities to develop as one of the potential resources for tourism development in the region. The region, specifically the art forms (handicrafts) has advantage linked to rich history of cultural practices; heritage and traditional art forms to develop on its strength and rise its share in emerging global market for arts and artistic products, an opportunity to tap the surging demand for handicrafts from domestic and international markets- developed countries such as USA, UK, Canada, Germany, France, Italy, etc. Moreover, developing industries such as tourism, fashion, retail, and realestate industry necessitates and contributing to further growth in demand for arts and handicrafts, and the recent emergence of Ecommerce and online platforms helps to harness the huge potentials of art forms or handicrafts. In this contest, Mithila's rich tradition of art and craft such as Mithila Painting revolving around its unique cultural practices and tradition aids to the strengthening of its potential and attract a sizeable number of international and domestic tourists to the region. However, the main threat's to the development and marketing of the Mithila Painting as a touristic resource has been the inability to address the internal constraints and external threats identified above. For instance, production and design issues, lack of innovation, issue of training of artists and availability of capital, the absence of effective supply chain, promotional and marketing mechanisms, alleged role of intermediaries, demand and supply balance and lack of efforts and strategic measures to develop and market of the art form. Moreover, external threats such as growing competition in domestic and international markets, viz. nearby regions of South Bihar, Jharkhand, Uttar Pradesh, West Bengal, and the North-East States, Rajasthan, Odisha, Jammu \& Kashmir, Tamil Nadu, Kerala, etc. 


\section{Integrated Marketing Approaches}

India, being part of one of the ancient civilization occupy a distinct position in the world's sociocultural history, heritage, cultural practices and traditions, which could be viewed in every region/ States of this land; evident in its diverse practices and the prominence of arts and crafts such as handicrafts, handlooms and several other artists products. However, some of the mare successful in communicating their strengthsto the markets, through effective promotion, development and strategic marketing and truly emerged as a brand in the global market.For instance, the art forms such as Kanchipuram Silk, Rajasthani Paintings, etc. promoted as one of the core components of tourism marketing-mix and significantly contributed to the tourism development in respective regions. In this context, the traditional folk painting of Mithila Region of Bihar, termed as- Mithila/ Madhubani Painting, recognized for its artistic and perceived value in domestic as well as international markets and successful to attract the attention of art lovers, researchers, and tourists from both developed and developing countries.

Thus, the study reveals that the art (handicrafts)should be recognized for its strength as well as existing opportunities in both domestic and international markets, must be identified as an integral part of tourist experience and the vigorous element of tourism offerings in order to achieve the goal of integrated marketing of the regional resources. However, in the rapidly changing macro and microenvironments and the factors, which are influencing the marketing strategies of business, particularly, the art forms and artistic products, worthy efforts for promotion and marketing has become increasingly vital for the success in the evergrowing competitive context. Moreover, under the broad theme of holistic marketing, integrated marketing as one of the key dimension of marketing, which "ensures multiple means of creating, delivering and communicating values that are employed and combined in the optimal manner"(Kotler, Keller, Koshy, \& Jha, 2009). 
The availability of information not only plays a significant role in the promotion and sales of artistic products but also link prospective buyers/ tourist to the art, and therefore, information on where to procure reliable and authentic artistic products/ crafts should be easily and unbiasedly available. There is a need to develop dedicated hubs in the region for the exhibition, promotion and sales of artisan products, viz. handicrafts, handlooms, and other crafts, designed in the line of ethnic village/ haats such as Surajkund Mela, Delhi Haat, Shilp Gram need to be encouraged. Workshops may be organized to strengthen the nitty-gritty associated with the manufacture of handicrafts; exposure to the expertise of proficient resource persons could leverage the production and make it perfect in all terms. Corporate Social Responsibility is a key factor that can add teeth to the integrated marketing efforts. Spomorship and patronization by corporate companies would certainly provide impetus to the quality of the handicraft items. The weavers and artisans need to be exposed to novel $R \& D$ techniques. It is almost significant that the younger generation takes anactive interest in the production of handicrafts; pride should be instilled in them to pursue the traditional vocalism. Furthermore, the revenue earned from the sale of handicrafts need to be channelised for the villages' development.

\section{Marketing \& Promotional Strategies}

The culture, either 'Intangible Cultural Heritage' (ICH) or 'Tangible Culture Resources' of humanity plays an important role in the development of any region or nation. The cultural expressions, for instance, the Art forms such as handicrafts and handlooms not only represents a set of shared attitudes, values, tradition, and practices of regions but at the same time provide an opportunity forpromotion and marketing of locally available resources. Consequently, the promotion and propagation help in conservation and sustainable development of the art forms, as well as the enhancement of socio-economic and cultural position and the prosperity of the artisan community. Studies found that despite many others, lack of proper marketing and related issues are the foremost problem faced by thousands of artisans of Mithila Painting in the region (M\&SEC, 1999). 
Promotion through national and international tourism offices and travel marks would essentially improve the marketing perspectives. Global exhibition and depiction in world-class publication including coffee table books, brochures, etc. could be a great thrust. Fraud writers may be invited for FAM trips to cover the indigenous handiworks through feature stories and showcase them by way of publications of international repute. Moreover, tax rebates and other incentives should be accorded for the artisans. Overall, the unique art forms such as handicraft/ handloom in general and traditional cultural expressions/ products- Mithila Painting, in particular, should be promoted under the banner of the tourism industry as souvenir or shopping item for tourists.

\section{Conclusion}

The study reveals that due to lack of promotional and marketing efforts and being a less explored destination for visitors/ tourists, the art form 'Mithila Painting' as well as the region has to be promoted along two dimensions. First, by offering a novel and authentic experience to tourists by showcasing cultural practices, traditions \& heritage and second, through empowering the native peoples through promotion \& marketing of indigenous resources/ cultural products- art forms, which gives a distinct representation of the people and could play a crucial role in tourism development in the region. Moreover, besides strategic promotion and marketing, quality control, design innovation, packaging, and branding are the main thrust area to tap the potential of Mithila Painting as a tourist resource. Literature confirmed the needs of promotion and marketing of art forms and laid emphasis due to two reasons. One; researchers acknowledged 'indigenous cultural tourism' as a potential aspect to promote means of development for the people and two; it would be an approach to sustain culture and uniqueness of the region. Thus, an effort to promote and market the imminent indigenous product and the region as a cultural destination would not only bring prosperity and benefits but also contribute to the conservation and preservation of unique cultural traditions in the region- requisite for sustainable development in the region. 
Moreover, the approach not only helps to uphold unique cultural heritage, traditional practices but also address the needs of promotion and marketing of indigenous cultural resources and shall bring benefits to tourism development in the region, and these ways provide an opportunity for progression to the practitioners of the art form/ natives in the region.

\section{References}

Archer, W. G. (1949). Maithil Painting. Marg, 3, 24-33.

Blundell, V. (1995). Riding the Polar Bear Express: And other encounters between tourists and First Peoples in Canada. Journal of Canadian Studies, 30(4), 28-51.

Butler, R., \& Hinch, T. (2007). Tourism and indigenous peoples: issues and implications. Journal of Ecotourism (Vol. 8). https://doi.org/ 10.1080/ 14724040902786641

Dasthgir, K. G., Anu Chandran, R. ., \& Jha, A. K. (2017). Development Discourse of Rural Tourism: Predilections, Performance and Prospects in India. In Y. V. R. Sibi P.S., Ravish Mathew, Priyakrushna Mohanty (Ed.), Contemporary Research and Practices in Tourism and Hospitality With Special Focus on Accessibility (First, pp. 106-117). Mumbai, India: Himalaya Publishing House.

DC (Handicrafts). (2016). Indian Handicrafts Sector Perfect Destination for Investors. Mumbai. Retrieved from http://www.handicrafts.nic.in/ CmsUpload/17082016020826Perfect Destination Small Brochure for web (1).pdf

DC (Handicrafts). (2017). Organisational Structure, office of the development commissioner (handicrafts). Retrieved June 28, 2017, from http://www.handicrafts.nic.in/pdf/org-structure.jpg

Department of Commerce. (2017). Handicraft Export: Commodity-wise Data. New Delhi: Export Promotion Councile for Handicrafts, Ministory of Commerce, GoI. Retrieved from http:// www.commerce.nic.in/eidb/Ecom8.asp?hs=970110

Department of Tourism, (Bihar). (2016). Bihar Tourism: Annual Report2016. Patna.

Deutschlander, S., \& Miller, L. J. (2003). Politicizing aboriginal cultural tourism: The discourse of primitivism in the tourist encounter. Canadian Review of Sociology \& Anthropology, 40(1), 27-44. https://doi.org/10.1111/j.1755-618X.2003.tb00234.x 
Dockery, A. M. (2010). Culture and Wellbeing: The Case of Indigenous Australians. Social Indicators Research, 99(2), 315-332. https://doi.org/10.1007/s11205-010-9582-y

Fuller, D., Buultjens, J., \& Cummings, E. (2005). Ecotourism and indigenous micro-enterprise formation in northern Australia opportunities and constraints. Tourism Management, 26(6), 891-904. https://doi.org/10.1016/j.tourman.2004.04.006

Furze, B., De Lacy, T., \& Birckhead, J. (1996). Culture, conservation and biodiversity: The social dimensions of linking development and conservation. Chichester: John Wiley.

Getz, D., \& Jamieson, W. (1997). Rural tourism in Canada: issues, opportunities and entreprenurship in aborignal tourism in Alberta. In D. Getz \& S. J. Page (Eds.), The business of rural tourism: International perspectives (First, pp. 93-98). London: Thomsan Business Press.

Ghosh, S. (2013). An Interactive need Assessment Survey and Design Study of Madhubani Painting of Jitbarpur, Madhubani district, Bihar (part-I). Patna. Retrieved from http://designclinicsmsme.org/ download/ DesignAwarenessSeminar/ProductDiversificationfromMadhubaniPai ntingClusterjitbarpur.pdf

Hall, M. (2007). Politics, power and indigenous tourism. In Tourism and Indigenous Peoples (pp. 305-318). https://doi.org/10.1016/B978-07506-6446-2.50031-4

Heinz, C. B. (2007). Documenting the Image in Mithila Art. Visual Anthropology Review, 22(2), 5-33. https://doi.org/ 10.1525/ var.2006.22.2.5

Hinch, T., \& Butler, R. (1996). Indigenous tourism: a common ground for discussion. In Tourism and Indigenous Peoples (pp. 3-19).

Hinch, T., \& Butler, R. (2007). Introduction: revisiting common ground. In Tourism and Indigenous Peoples (pp. 1-12). https:// doi.org/ 10.1016/ B978-0-7506-6446-2.50005-3

Jagran Post, E. (2011). Demand for Mithila state gains momentum, politicians join demonstration at Jantar Mantar. Jagran Post. New Delhi. Retrieved from post.jagran.com/demand-for-mithila-stategains-momentum-politicians-join-demonstration-at-jantar-mantar1312256949

Jain, J. (1989). Ganga Devi: Tradition and expression in Madhubani painting. Third Text, 3(6), 43-50. https://doi.org/ 10.1080/ 09528828908576213 
Jha et al.

Kleinert, S. (2010). Aboriginal Enterprises: negotiating an urban Aboriginality. Aboriginal History, 34(1), 171-196.

Kotler, P., Keller, K. L., Koshy, A., \& Jha, M. (2009). Marketing management : a South Asian perspective (13th ed.). New Delhi: Pearson Prentice Hall.

Kumar, D. (2005). Mithila Miscellany (First). Darbhanga: Mithila Lok Prakashan.

M\&SEC, M. (1999). Special Study Report on "Mithila Painting." Madhubani.

M\&SEC Madhubani. (1997). Status Report on "Mithila Painting." Madhubani.

Mathur, J. C. (1966). Domestic Arts of Mithila. Marg, 20, 43-46.

McIntosh, A. J. (2004). Tourists' appreciation of Maori culture in New Zealand. Tourism Management, 25(1), 1-15. https://doi.org/ 10.1016/ S0261-5177(03)00058-X

McIntosh, A. j., \& Ryan, C. (2013). The marketing perspective of indigenous tourism: opportunities for business development. In R. Butler \& T. Hinch (Eds.), Tourism and Indigenous Peoples (pp. 73-83). New York: Routledge.

Ministry of Textiles. (2017). A compendium of Indian Handicrafts Eamp; Handlooms Covered under Geographical Indications (GI). New Delhi. Retrieved from http://www.handicrafts.nic.in/ CmsUpload/ 12222017102212GI BOOK FINAL 2-5-17_resized.pdf

Ministry of Tourism. (2002). National Tourism Policy 2002. New Delhi: Ministry of Tourism Government of India.

Mishra, K. K. (n.d.). Mithila Paintings: Past, Present and Future. Retrieved June 13, 2017, from http:/ / www.ignca.nic.in/kmsh0002.htm

Mishra, V. (1978). Mithila Art and Aechitecture. Allahabad: Mithila Prakashan.

Nigam, D., \& Ranjan, R. (2014). Tourism development through indigenous art of Mithila: a study of Mithila painting (Madhubani arts). International Journal of Tourism and Travel, 7(1\&2), 1-6.

O'Malley, L. S. S. (1907). Bengal District Gazetteers "DARBHANGA" (First (Rep). New Delhi: Logos Press.

Oberoi, J. (2012). The living tradition of Mithila paintings - State of the Art. Retrieved June 13, 2017, from https://blog.saffronart.com/ 2012/11/06/the-living-tradition-of-mithila-paintings/

Pitchford, S. (2006). Identity tourism: A medium for Native American stories. Tourism Culture \& Communication, VI, 85-105.

Rekha, N. (2003). Harijan Paintings of Mithila. Marg, 54, 66-77. 
Rekha, N. (2010). From folk art to fine art: changing paradigms in the historiography of Maithil painting*. Journal of Art Historiography Number, (2). Retrieved from https:// arthistoriography.files.wordpress.com/2011/02/media_152490_en.pdf

Roy, L. (2015). Indigenous cultural heritage preservation: A review essay with ideas for the future. International Federation of Library Associations and Institutions, 41(3), 192-203.

Roy Chaudhury, P. C. (1964). Bihar District Gazetteers "Darbhanga." Patna: The Superintendent Seoretariat Press, Bihar.

Ryan, C. (1997). Tourism and indigenous peoples. Tourism Management (Vol. 18). https:/ / doi.org/10.1016/S0261-5177(97)84400-7

Ryan, C., \& Page, S. (2000). Tourism Management: Towards the New Millennium. Advances in Tourism Research Series. https://doi.org/ 10.1016/S0160-7383(01)00018-4

Sharma, E. (2015). Trible Folk Art of India. Journal of International Accadmic Research for Multidiciplinery, 3(5), 300-308.

Sharma, E. (2016). Digitalization of Motifs Based on Indian folk Paintings through CAD and their Adaptation on Apparels using Digital Printing Technique. Research Journal of Family, Community and Consumer Sciences, 4(1), 1-10.

Sharma, R. P. (1979). Mithila ka itihasa (Secound). Darbhanga: KSDSU.

Sibi, P. S., \& Swamy, G. A. (2015). Scope and potential for indigenous tourism-an analytical study in Wayanad, Kerala. ZENITH International Journal of Multidisciplinary Research, 5(11), 60-69.

Sibi, P. S., \& Swamy, G. A. (2016). Indigenous Tourism -An Ideal Sustainable Tourism Model for Wayanad, Kerala. SAJTH, 9(2), 111123. Retrieved from http://www.sajth.com/journal/wp-content/ uploads/2016/09/Indigenous-Tourism--An-Ideal-SustainableTourism-Model-for-Wayanad-Kerala.pdf

Sinclair, R. (2003). Indigenous research in social work: The challenge of operationalizing worldview. Native Social Work Journal, V(1), 117-139.

Singh, N. N. (2004). Geographical Expression Through The Historical Madhubani Paintings. Mithila Historical Journal, I(1), 88-96.

Singh, T. V., \& Singh, S. (2000). Tourism in India: development, performance and prospects. In C. M. Hall \& S. Page (Eds.), Tourism in South and Southeast Asia (First, pp. 225-232). Oxford: ButterworthHeinemann. 
Sinha, N. (1999a). Bihar-The land of Alluring Handicrafts. In Tourism Perspectives in Bihar (First, pp. 15-19). New Delhi: APH Publishing Corporation.

Sinha, N. (1999b). Madhubani Painting. In Tourism Perspectives in Bihar (First, pp. 21-25). New Delhi: APH Publishing Corporation.

Sinha, N. (1999c). Tourism Perspective in Bihar. New Delhi: APH Publishing Corporation.

Sinha, N. N. (2003). Madhubani/ Mithila Painting: its History. In LXIV Session The Indian History Congress, (pp. 51-61). Mysore: University of Mysore, Mysore, Karnataka.

Sinha, N. N. (2004). Historical Mithila Folk painting and Its Transformation. Historical Compilation, VI(VI), 100-104.

Sinha, N. N. (2007). Philosophical Expression Through the Cultural Mithila Paintings. In M. Ghosh (Ed.), Musings on Philosophy: Perennial and Modern (First, pp. 90-92). New Delhi: Sundeep Prakashan.

Sinha, N. N. (2010). MADHUBANI: A CONTEMPORARY HISTORY (1971-2011). In Proceedings of the Indian History Congress (Vol. 71, pp. 1243-1250).

Smith, V., \& Butler, R. W. (1996). Indigenous tourism: the four H's. In Tourism and Indigenous Peoples (pp. 283-307).

Smith, V. L. (1996). The Four Hs of Tribal Tourism: Acoma -a Pueblo Case Study. Progress in Tourism and Hospitality Research, 2, 295-306. https://doi.org/10.1002/pth.6070020310

Sohoni, S. V. (1982). Review Paper | Madhubani Painting: by Dr. Upendra Thakur. Annals of the Bhandarkar Oriental Research Institute, 63(14), 362364. Retrieved from http://www.jstor.org/stable/41693025

Swain, M. B. (1989). Developing ethnic tourism in Yunnan, China: Shilin Sani. Tourism Recreation Research, 14(1), 33-39.

Textile Policy, I. (2000). National Textile Policy- 2000. New Delhi: Ministory of Textiles, Government of India. Retrieved from http://www.texmin.nic.in/sites/default/files/policy_2000.pdf

Thakur, U. (1988). History of Mithila (ca. 3000 BC-1556 AD) (Secound). Darbhanga: Mithila Institute.

UMSAS. (2017). Madhubani (Mithila) Painting. Retrieved July 1, 2017, from http://www.umsas.org.in/en/bihar-arts-crafts/madhubanipainting/ 
UNESCO. (2017). UNESCO Office in Cairo (2009-2014) Tangible Cultural Heritage. Retrieved June 17, 2017, from www.unesco.org/new/ en/ cairo/culture/tangible-hcultural-heritage/

UNO Factsheet. (2016). Who are indigenous peoples? Retrieved February 10, 2017, from http://www.un.org/esa/ socdev/ unpfii/ documents/5session_factsheet1.pdf

Weaver, D. (2010). Indigenous tourism stages and their implications for sustainability. Journal of Sustainable Tourism, 18(1), 43-60. https:// doi.org/10.1080/09669580903072001

Xaxa, V. (1999). Tribes as Indigenous People of India. Economic \& Political Weekly, 34(51), 3589-3595. https://doi.org/10.2307/4408738

Zeppel, H. (2001). Aboriginal cultures and indigenous tourism. Special Interest Tourism, 232-259. 